\title{
Review:
}

\section{Flavonoids as Antidiabetic Agents}

\section{Yana Cahyana* and Tsani Adiyanti}

Department of Food Technology, Faculty of Agro-Industrial Technology, Universitas Padjadjaran, Jl. Raya Bandung Sumedang KM 21, Jatinangor 40600, West Java, Indonesia

* Corresponding author:

email:y.cahyana@unpad.ac.id

Received: August 7, 2020

Accepted: November 30, 2020

DOI: $10.22146 / \mathrm{ijc} .58439$

\begin{abstract}
Flavonoids are polyphenol compounds that exert many potential health benefits, including diabetes type-II, which is the third most common disease that causes death, right after cancer and cardiovascular diseases. The excessively high level of blood glucose has been believed to trigger type II diabetes. The aim of this review is to describe the flavonoid's ability as an alternative treatment for diabetes type-II patients. This paper addresses several aspects in which flavonoids may impart a pivotal role in starch digestion, such as the interaction of flavonoids with enzymes involved in starch hydrolysis, the role of flavonoids in inhibiting glucose absorption, as well as the interaction of flavonoids with starch to form a complex resistant to hydrolysis. Further studies, however, are suggested to extensively carry out, particularly the ones dealing with the intervention study using human volunteers to reveal the role of flavonoids in the real applications. The data on human intervention studies are still rare and can further be exploited using metaanalysis to have firmer results. Flavonoids in the food matrix are more realistic to perform to reveal the effect of interaction with other compounds, which may affect the mechanism of flavonoids interaction or their bioavailability.
\end{abstract}

Keywords: antidiabetic; flavonoids; interactions of flavonoids; starch digestion

\section{- INTRODUCTION}

Diabetes mellitus (DM) is a metabolic disease caused by a chronic failure of metabolic function in the human body as a result of lack of insulin secretion and a decreased insulin tissue response to metabolize carbohydrates, proteins, and lipids. This disease is featured by an increase in blood glucose levels as well as an increased risk of vascular complications such as cancer [1]. Diabetes mellitus has two types. Type I diabetes is characterized by pancreatic $\beta$ cell destruction because of autoimmune disease. This leads to the patients dependency on exogenous hormones. Conversely, in type II diabetes, the body becomes resistant to the effects of insulin and/or does not produce enough insulin [2]. The most common case of diabetes is type II diabetes. Diabetes can increase the risk of cancer, heart disease, and other complications. [3]. The prevalence of diabetes in 110 countries is projected to increase from 366 million in 2011 to 552 million in 2030 for the 20-79 year age group. Most diabetics live in low and middle-income countries [4].

Insulin injection is one of the most common treatments for diabetics. However, some people refuse insulin injections due to psychological factors (feeling afraid of the pain caused by daily injections), the formation of addictive effects, the occurrence of hypoglycemia, and the occurrence of insulin resistance in the body that occurs in the jejunum [5-6]. A number of studies have been conducted to address the diabetic problem, including flavonoids that have been believed to exert health benefits, including antidiabetic agents [7-9].

This paper describes the likely mechanisms of flavonoids as antidiabetic agents particularly related to starch digestion. In general, the antidiabetic effect of flavonoids may be related to their role in glucose metabolism or as an antioxidant against oxidative stress. The former is the focus of the review of this paper, while 
the latter is out of the scope of this paper. In terms of the role of flavonoids in glucose metabolism, the antidiabetic properties of flavonoids result from the inhibitory effect against digestive enzymes [10-11]. Other mechanisms may be linked to the effect on glucose absorption through small intestinal cells [12] and the interaction of flavonoids with starch to form resistant starch [13]. The fact that flavonoids consist of vastly different compounds, it is important to begin the discussion with flavonoids classification followed by the starch hydrolysis process.

\section{- FLAVONOIDS}

Flavonoids are one of the secondary metabolites included in the group of polyphenols found in plants. The compounds have a carbon framework of C6-C3-C6. The two group rings of $\mathrm{C} 6$ (benzene rings) $\mathrm{A}$ and $\mathrm{B}$ are connected by 3 carbons (Fig. 1). Flavonoids can be classified into 6 groups (Fig. 2), including flavonols, flavan-3-ols (flavanols), flavones, anthocyanins, isoflavones, and flavanones [14]. Flavonoids can be naturally found in foods such as cereals, vegetables, fruits, and nuts, serving as protectors for these plants [15]. The compounds are also responsible for giving color to fruit and flower. In addition, flavonoids exhibit health benefits such as anti-cardiovascular, antidiabetic, obesity, and anticancer in humans $[7-9,16]$.

\section{Flavonols}

Flavonols are the main compounds of the flavonoids group, which have an important role in plant growth, development, and resistance, such as damage due to UV irradiation and insect pest [17]. Meanwhile, in the human body, flavonoids, especially quercetin, exhibit antimicrobial and antioxidant activities so that they play a role in preventing cancer, cardiovascular, and antiinflammatory. In addition, flavonols possess an antihistamine effect, which is used as an antiallergic drug.
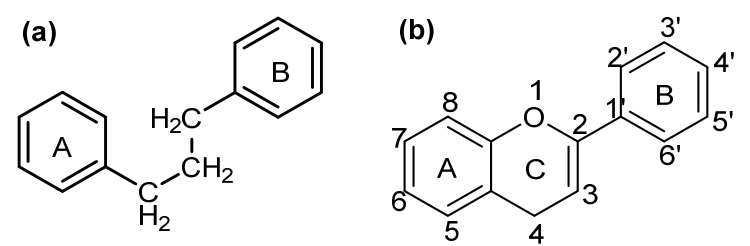

Fig 1. (a) Flavonoid framework; (b) Numbering system
Flavonols can be used to reduce high blood pressure in people with hypertension and improve the barrier function of human intestinal cells so that it does not cause diarrhea [18-20]. In another study, it was found that the aglycone form of flavonols in lotus leaf charcoal increased hemostatic effects [21]. The most common flavonols are kaempferol, quercetin, and myricetin (Fig. 2 ), with the main flavonols, quercetin 3-O-glycoside [2223].

\section{Flavones}

Flavones have a structure consisting of 2 benzene rings (rings $\mathrm{A}$ and $\mathrm{B}$ ) connected by 3 carbon chains forming a closed pyranone ring (ring $\mathrm{C}$ ) that joins ring A (Fig. 2) [24]. This structure is closely related to flavonols, but in terms of the occurrence in plants, flavones are found in smaller quantities than flavonols. Examples of flavone compounds are luteolin, apigenin, and chrysin [16].

Flavones in the form of C-glycoside, demonstrate an important role in plants, including as an antioxidant and pigment for UV absorption. In addition, flavones are also used to regulate the interaction of plants with microbes and insects in defense of the plants [25]. Flavones are non-essential nutrient compounds that provide additional nutraceutical effects in food [26]. Flavones have several health benefits, including anticancer properties. This effect is related to the ability of flavones to interact with human estrogen receptors in cancer prevention through a mechanism similar to tamoxifen that is often used medically. As such, flavones are often classified as phytoestrogen [27]. In addition, flavones exhibit antifungal and antidiabetic properties $[24,28]$. Flavones are also known to be used as antioxidants because they can inhibit the action of the xanthine oxidase enzyme from producing Reactive Oxygen Species (ROS). This inhibition can prevent endothelial damage during acute inflammation and restore the function of the mitochondria [29].

\section{Flavan-3-ols (Flavanols)}

Flavan-3-ols, or often referred to as flavanols, are the most complex group of flavonoids based on their structure (Fig. 2). The compounds include catechins in 


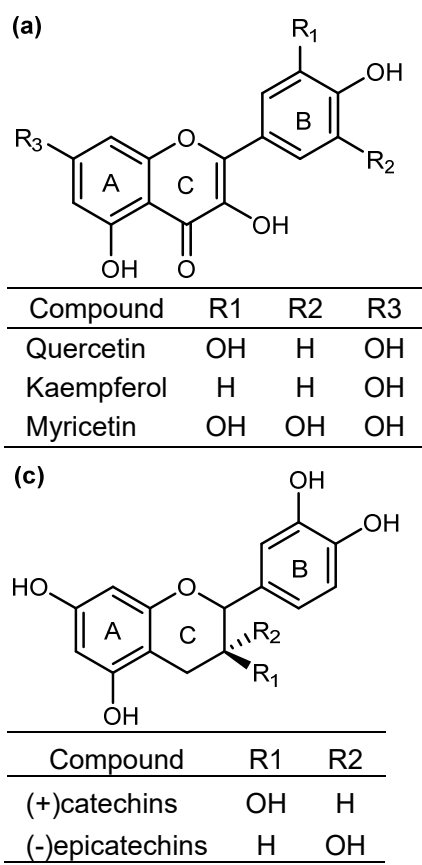

(e)<smiles>[R]c1c(O)cc2occ(-c3ccc(O)cc3)c(=O)c2c1[R1]</smiles><smiles>[R6]O[C@H]1O[C@H](Oc2cc3occ(-c4ccc(O)cc4)c(=O)c3c([R3])c2[R])[C@H](O)[C@@H]1O</smiles>

\begin{tabular}{|c|c|c|c|}
\hline Compound & R1 & R2 & \\
\hline Daidzein & $\mathrm{H}$ & $\mathrm{H}$ & \\
\hline Genistein & $\mathrm{OH}$ & $\mathrm{H}$ & \\
\hline Glycitein & $\mathrm{H}$ & $\mathrm{OCH}$ & \\
\hline Compound & R3 & R4 & R5 \\
\hline Daidzin & $\mathrm{H}$ & $\mathrm{H}$ & $\mathrm{H}$ \\
\hline Genistein & $\mathrm{OH}$ & $\mathrm{H}$ & $\mathrm{H}$ \\
\hline
\end{tabular}
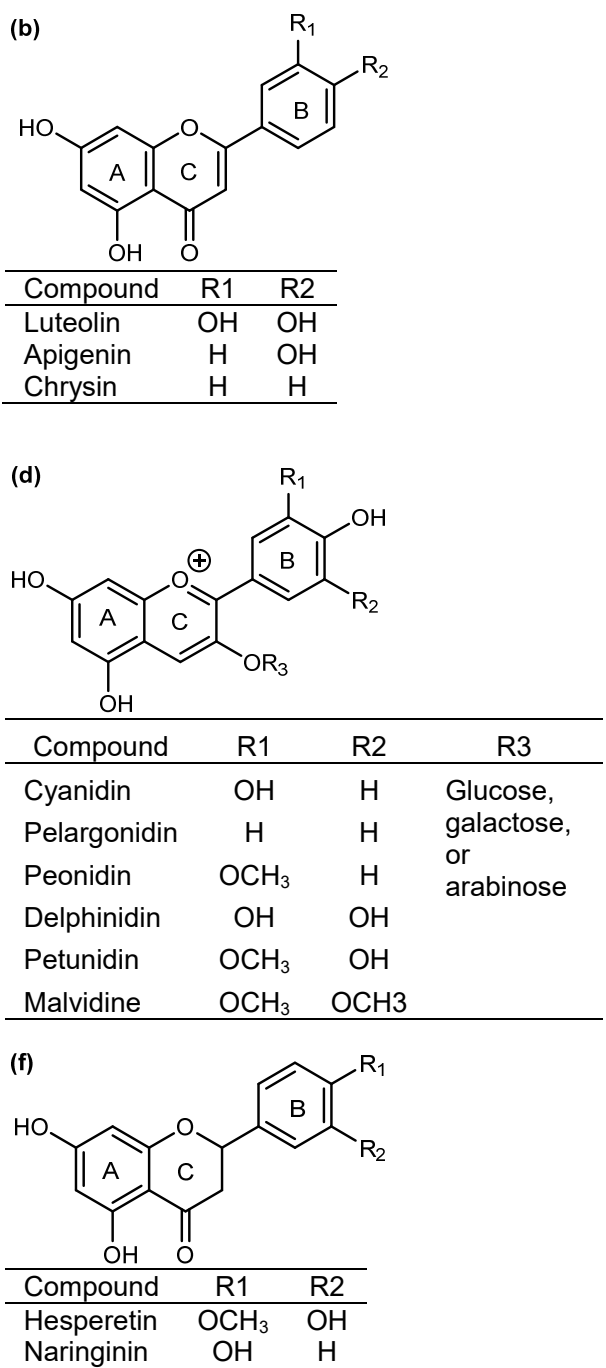

Fig 2. Types of flavonoids (a) Flavonols; (b) Flavones; (c) Flavanols; (d) Anthocyanins; (e) Isoflavones (aglycone and glycoside); (f) Flavanones

the form of monomers and epicatechins as their isomers found in nature. In addition, there are monomers whose distribution is more limited such as epiafzelekin, theaflavins, proanthocyanidin as oligomers, and a polymer form known as tannin [30]. These compounds are a group of polyphenol present significantly in tea leaves, such as catechins in green tea [31]. In the human body, the reducing effect on blood glucose levels following the consumption of this compound is suggested to result from its effect on inhibiting digestive enzyme activity such as $\alpha$-amylase and $\alpha$-glucosidase [32]. In addition, flavanols are known to reduce blood pressure or hypertension, thereby reduction in the risk of cardiovascular disease, especially in the elderly [33-34]. 
Flavanols also possess antioxidant effects, antidepressant properties, and an impact on body weight loss, thereby reducing the effect on obesity [35-37]. Flavanols rich food intake can reverse vascular dysfunction in diabetics. Therefore the compounds are a potential alternative to treat patients with cardiovascular disease [38].

\section{Flavanones}

Flavanones are the first product of the flavonoid biosynthesis pathway, where there is a chiral C in C2. In addition, these compounds do not have a $\mathrm{C} 2-\mathrm{C} 3$ double bond so that the structure is very reactive (Fig. 2) and can undergo hydroxylation, glycosylation, and $\mathrm{O}$-methylation reactions [23]. The antioxidant properties of flavanones are believed to be related to their chemical structures [39]. The most commonly found flavanones are naringenin, hesperidin, and hesperetin [40]. In addition, other types of flavanones are also found, such as pinocembrin, pinostrobin, and alpinetin [39]. Flavanones and their derivatives exhibit antioxidant and anti-inflammatory properties in the human body by inhibiting the formation of nitric oxide (NO) from macrophage cells induced by lipopolysaccharides (LPS). Flavanones are also reported to play a role as an anticancer [41-42].

\section{Isoflavones}

The structure of isoflavones is shown in Fig. 2 [23]. The aglycone forms of isoflavones are genistein, daidzein, and glycitein [43], whereas isoflavones available in the form of $\beta$-glycosides are daidzin and genistin, and glycitin [44].

The role of isoflavones in a plant is to protect plants from pathogenic microbial attack [45]. While in the human body, isoflavones show their role in preventing and alleviating several diseases, including osteoporosis in women [46], diabetes, heart disease, Kawasaki, and Alzheimer disease, and exhibit antitumor, antiaging properties [47-48]. In addition, isoflavones also provide a protective effect against breast cancer in postmenopausal women [49].

\section{Anthocyanins}

Anthocyanins are commonly found in fruits and flower tissues, which provide colors ranging from pink to orange to red, purple, and also blue [50]. The function of anthocyanins in plants is to attract insects in the pollination process. Anthocyanins also protect the plant from the absorption of excess light. The most common anthocyanins are pelargonidin, cyanidin, peonidin, delphinidin, maldivine, and petunidin [51]. The difference in these compounds can be seen in Fig. 2.

In the human body, anthocyanins show health benefits and can suppress postprandial glycemia because the compounds inhibit digestive enzyme activity in the intestine. These interactions are influenced by several environmental factors, such as $\mathrm{pH}$, temperature, and chemical structure [52]. Anthocyanins also inhibit insulin secretion in the body and glucose absorption (2deoxy-D-glucose (2DG)) [53-55]. In addition, anthocyanins demonstrate antiobesity and anticancer properties [56-57]. Anthocyanins are reported to have low bioavailability [58]. This low bioavailability may lead to low effectiveness of anthocyanins as antioxidants but sufficient to modulate gene expression.

\section{- a-AMYLASE AND a-GLUCOSIDASE AS DIGESTIVE ENZYMES}

The $\alpha$-amylase enzyme is the common name of $\alpha$ 1,4-glucan-4-glucanohydrolase from the glycosidase hydrolase $(\mathrm{GH})$ family. This enzyme is found in saliva and the pancreas [59-60]. $\alpha$-Amylase can be isolated from several microbes such as Bacillus atrophaeus NRC1 [61], Gram-positive bacteria from soil samples [62], plants, animals, and fungi [63]. This enzyme works as a catalyst in the process of breaking down starch molecules, their derivatives, and other carbohydrate polymers into shorter chains (maltose and maltooligosaccharides) by hydrolyzing and cutting the $\alpha-1,4$ amylose chain glycoside bonds in the digestive system $[10,61,64]$.

Another enzyme that plays a part in the digestive process of starch is a-glucosidase. This enzyme is located in the small intestinal epithelium or on the surface of the "brush border" membrane of small intestinal cells. $\alpha$ glucosidase is involved in the final step in the process of carbohydrate digestion into monosaccharides that are directly related to the absorption of blood glucose levels in the jejunum [11]. Given its important role in the 
absorption of glucose in the digestive tract, inhibiting the activity of this enzyme can result in the reduction of the glucose absorption and prevent postprandial hyperglycemia in patients with type II diabetes mellitus [65]. Therefore, both the $\alpha$-amylase and $\alpha$-glucosidase enzymes are targets for the development of antidiabetic drugs.

\section{- GLUCOSE PRODUCTION IN THE BODY}

The $\alpha$-amylase enzyme produced by the pancreas enters the small intestine and helps the digestive process by hydrolyzing complex carbohydrates. The hydrolysis process by the enzyme requires the role of calcium ions $\left(\mathrm{Ca}^{2+}\right)$ [60]. Hydrolyzed starches experience further cleavage by $\alpha$-glucosidase. The mechanism of starch hydrolysis is shown in Fig. 3. $\alpha$-Glucosidase is an enzyme that catalyzes the final process of carbohydrates digestion in the intestine and plays a direct role in the process of glucose uptake in the blood [11]. When the concentration of glucose absorbed by the blood is high, it leads to an increase in the glycaemic index and may cause diabetes.

\section{- THE ROLE OF FLAVONOIDS AS ANTIDIABETIC}

Flavonoid compounds have been believed to have an anti-diabetic effect because they can inhibit the $\alpha$-amylase and a-glucosidase enzymes. The inhibition depends on the interaction of hydrogen bonds between hydroxyl groups on flavonoids and enzyme catalytic residues. This interaction between the enzyme and flavonoids leads to reduced digestion of starch and postprandial glycemia [66]. Another role of flavonoids is to interact with starch and form a complex which is difficult to digest (resistant) [13]. Flavonoids can also inhibit the process of glucose absorption by inhibiting glucose transporters [67]. The schematic mechanism of flavonoids on starch digestion and glucose absorption is presented in Fig. 4.

\section{Interaction of Flavonoids with Digestive Enzymes}

The enzymes of $\alpha$-amylase and $\alpha$-glucosidase are involved in breaking down starch into glucose. The high concentration of glucose present in the blood triggers an insulin response to reduce the blood glucose level. It is associated with type II diabetes when insulin resistance occurs. Therefore, if the activity of the enzyme can be reduced, then the possibility of type II diabetes in humans would decrease [64]. Many compounds, including flavonoids, show inhibitory activity against $\alpha$ amylase and $\alpha$-glucosidase. Therefore, these compounds can be used as antihyperglycaemic candidates [68]. Several factors may affect the interaction of the enzyme with flavonoids. The structure of flavonoids has been believed to affect the flavonoid affinity to the enzymes. Substitution of hydroxyl groups $(-\mathrm{OH})$ with glycosides has been reported to render the affinity of glucose binding with the $\alpha$-amylase decreased [64].

Flavonoid compounds show interactions with the $\alpha$-amylase and $\alpha$-glucosidase to form complex structures through hydrogen bonds and hydrophobic interactions. The hydrogen bonds occur between hydroxyl and carbonyl groups in the flavonoid structure with the active residue of the enzyme [69]. The different structure of flavonoids results in enzyme inhibition with different
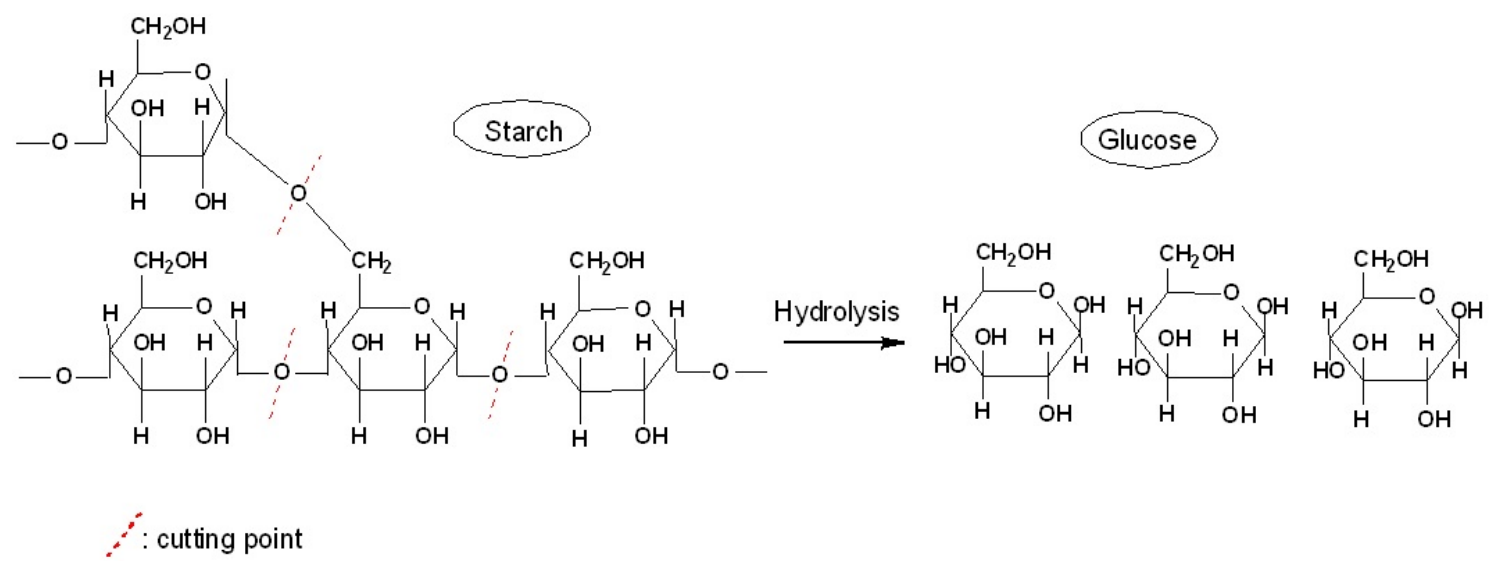

Fig 3. Schematic hydrolysis of starch by amylase enzyme [70] 


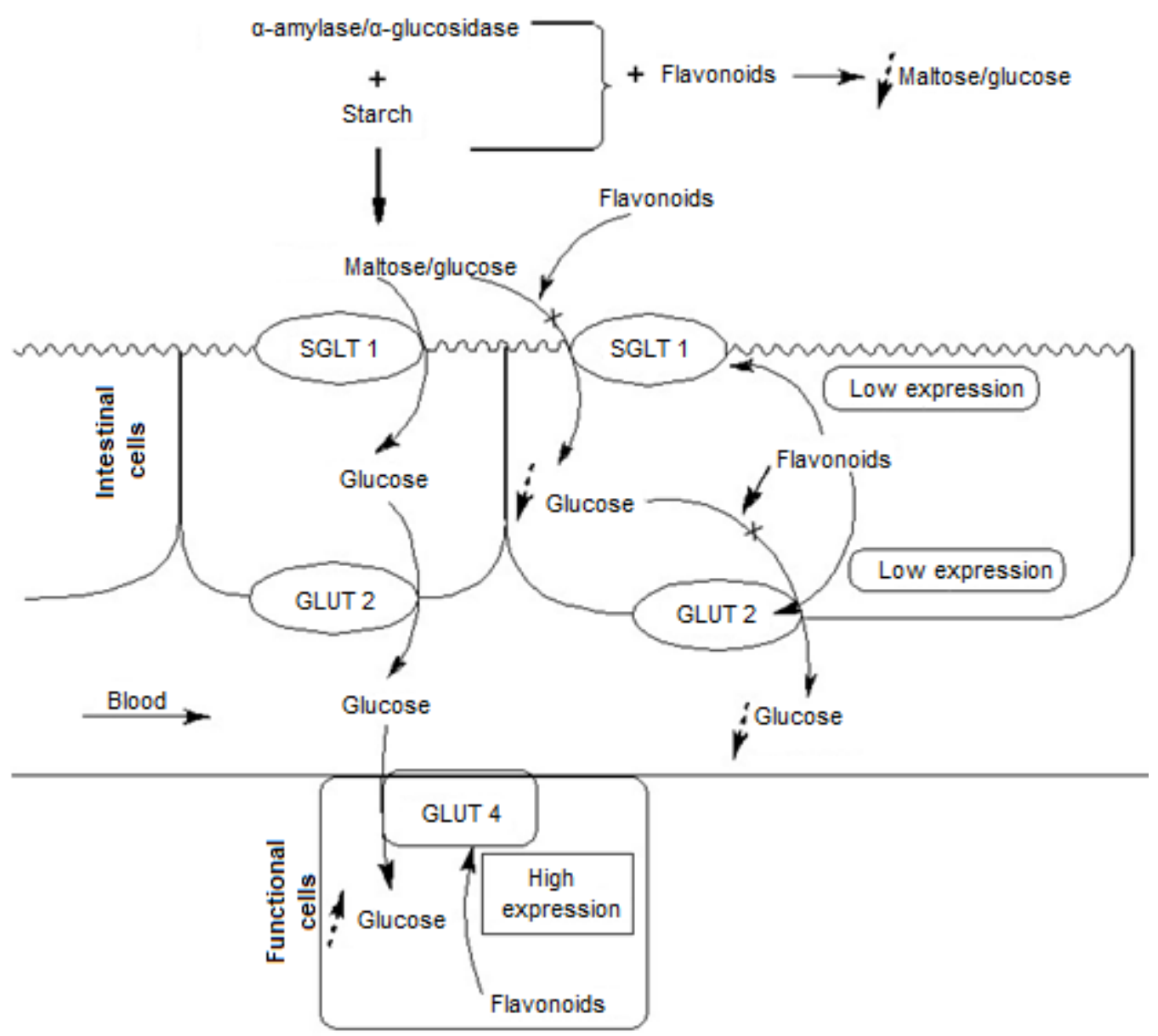

Fig 4. Schematic mechanism of flavonoid effect on starch digestion and its absorption

$\mathrm{IC}_{50}$ values. In the previous study, it is found that flavonols (quercetagetin) and flavones (eupafolin) exhibit the inhibition with $\mathrm{IC}_{50}$ of 10.2 and $48.0 \mu \mathrm{M}$, respectively. The maximum inhibition is approximately $97.6 \%$ and $99.4 \%$ for flavonols and flavones, respectively [66].

Flavonoids extracted from Artocarpus altilis also exhibit inhibition activity against $\alpha$-glucosidase, with the inhibition type being a non-competitive one [71]. Another source of flavonoids, such as Samama plant extract, has been demonstrated to inhibit $\alpha$-glucosidase activity [72].

The interaction between the hydroxyl group of flavonoids and the residue present in enzymes induces an opening of enzymatic structures by decreasing $\alpha$-helix and increasing random coils, thus masking the active site. This results in inhibition of substrate binding to the enzyme, and consequently, the enzyme activity decreases. The decrease in the enzyme activity leads to a reduced glucose absorption resulting from starch breakdown [73].
According to an in silico study, the structure of flavonoids that shows interactions with enzymes is the hydroxyl $(\mathrm{OH})$ group present in ring $\mathrm{A}$ in position $\mathrm{C} 7$ and the hydroxyl group in ring B in position C4' [66].

\section{Interaction of Flavonoids with Starch}

Interaction of flavonoids with starch through covalent bonds has been reported in another study. This interaction results in resistant starch, which shows a lower digestibility by $\alpha$-amylase and $\alpha$-glucosidase [13]. In a study using Surface Plasmon Resonance (SPR), it was demonstrated that those flavanones could bind to starch to form complexes. The ability to form a complex between flavonoids with starch depends on the position of the hydroxyl group, suggesting that the different flavonoids would have different binding capacities [74]. The retrograded starches are known to be resistant to digestion by direct inhibition of the $\alpha$-amylase enzyme. 
Starch retrogradation occurs when polymer chains of gelatinized starch reassociate and recrystallize through hydrogen bonds [74].

\section{The Role of Flavonoids in Inhibiting Glucose Absorption}

Glucose cannot pass through cell membranes by passive diffusion due to its relatively large size. It requires a family of specific transport proteins that can carry glucose through the cell membrane. The type of glucose transporter varies depending on the need for glucose in various tissues [75]. Glucose transporters consist of two main types/groups, namely SGLT and GLUT. Sodium Glucose Transporter (SGLT) is also known as an active co-transporter or symporter energized by proton or sodium gradients. SGLT1 is responsible for the absorption of glucose in the intestinal tract by active transport mechanisms. The second type is the Glucose Transporter (GLUT), which acts as a passive diffusion device for glucose to cross the membrane or tissue barriers by energy [67]. Considering the glucose transport across the membrane, alleviating diabetes mellitus can be done by reducing glucose absorption through the inhibition of glucose transporters such as GLUT2 and SGLT1.

According to structural similarity, glucose transporters (GLUT) can be divided into three subclasses, namely class I (GLUTs 1-4), which is a glucose transporter, class II (GLUT 5, 7, 9 and 11) which is fructose transporters, and class III (GLUTs 6, 8, 10, 12 and HMIT1) [76]. Glucose transporter is closely related to the level of glucose in the blood. Therefore many studies are conducted on the interaction of flavonoids with glucose transporters to reduce the risk of diabetes.

Type II diabetes can occur due to high glucose absorption into blood and glucose uptake from blood into functional cells. The uptake involves glucose transporters [77]. GLUT4 is one of the glucose transporters that is closely related to type II diabetes because glucose absorption by muscle and insulin-induced fat is mediated by GLUT4. In muscles, this transporter also takes glucose after muscle contraction [77].

Glucose, which is absorbed through the intestine, will be distributed throughout the body tissues. In the process of distribution, glucose requires a means of transport to cross the cell surface involving a transport protein called GLUT. The protein involved is a polytrophic membrane protein, in which this protein forms a watery pore and crosses the membrane so that glucose can move [76]. GLUT1 and GLUT4 are involved in the transport of glucose through the cell membrane. In diabetic patients, decreased GLUT4 translocation levels can reduce glucose absorption and increase insulin resistance [78]. Reduction in blood glucose levels occurs through three main mechanisms, including (i) increased absorption of glucose by peripheral tissue through GLUT 4 translocation; (ii) inhibition of lipolysis and promotion of lipogenesis, and (iii) increase in storage and utilization of glucose in the liver [78].

One of the flavonoids which are known to reduce blood sugar concentration is quercetin extract from berries. This compound is involved in the inhibition of glucose absorption in the intestine [78]. The inhibition of glucose absorption by flavonoids in intestinal cells could occur through at least two mechanisms. The first one is by direct inhibition of glucose transporter of SGLT1 and GLUT2 as observed in a study using strawberry anthocyanins [79]. The other mechanism is by inhibiting SGLT1 and GLUT2 expression by flavonoids, as demonstrated in another study [80]. The inhibition of glucose in the intestinal lumen either by direct inhibition of glucose transporters activity or their expression results in a reduced blood glucose level. The inhibition also leads to an accumulation of glucose products in the intestinal lumen. The glucose product accumulation could inhibit hydrolysis reaction, thereby retarding starch hydrolysis [81]. The decrease in blood glucose level can also occur due to the increase in glucose uptake from the blood by functional tissue cells. Given that the glucose uptake involves glucose transporter of GLUT4, increasing the transporter expression could increase the glucose uptake by cells hence a reduced blood glucose level. Studies reported that flavonoids can increase GLUT4 expression leading to an elevated glucose uptake and a lower blood glucose level [82]. 


\section{- FOOD AS SOURCE OF FLAVONOIDS}

Flavonoid intake in the body can be obtained from several food sources. Examples of several food sources from each class of flavonoids include flavonols which can be found in daily foods such as apples, onions, broccoli, tea, olives, kale, cranberries, lettuce, beans, and peanut seeds $[23,83]$. In addition, flavones can be found in celery, parsley, in the form of 7-O-glycosides, as well as in olives and tangerines [23]. Other flavonoid compounds, flavanols, can also be obtained from foods such as nuts, cereals, red wine, chocolate, and apples [33-34,84]. Meanwhile, sources of anthocyanins are found in red fruits such as cherries, plums, strawberries, raspberries, blackberries, grapes, red grapes, and black currants or black grapes. Cyanidin is the most common type of anthocyanin in food [23]. The source of flavanones is found in acidic fruits such as oranges and their preparations [85-86]. Soybeans are the most common food source that contains isoflavones $[41,87]$. Different types of flavonoids and their content in various food are shown in Table 1.

Table 1. Food Sources of flavonoids

\begin{tabular}{|c|c|c|c|c|}
\hline Source & Flavonoid type & Compound & Mean content & Ref \\
\hline \multirow[t]{3}{*}{ Carica papaya } & Flavonols & Quercetin-3-rutinoside & $14.54 \mathrm{mg} / \mathrm{g}$ & [88] \\
\hline & & Myricetin-3-rhamnoside & $9.78 \mathrm{mg} / \mathrm{g}$ & \\
\hline & & Kaempferol-3-rutinoside & $10.15 \mathrm{mg} / \mathrm{g}$ & \\
\hline \multirow[t]{2}{*}{ Blue Berry } & Flavonols & Myricetin-3-O-arabinoside & $31.2 \mathrm{mg} / 100 \mathrm{~g}$ dry weight & [89] \\
\hline & & Quercetin-3-O-arabinoside & $18.97 \mathrm{mg} / 100 \mathrm{~g}$ dry weight & \\
\hline \multirow[t]{5}{*}{ Lingonberry } & Flavonols & Quercetin-3-O-xyloside & $8.9 \mathrm{mg} / 100 \mathrm{~g}$ dry weight & [89] \\
\hline & & Quercetin-3-O-arabinoside & $7.6 \mathrm{mg} / 100 \mathrm{~g}$ dry weight & \\
\hline & & Quercetin-3-arabino-furanoside & $49.3 \mathrm{mg} / 100 \mathrm{~g}$ dry weight & \\
\hline & & Quercetin-3-O-(4"-HMG)-rhamnoside & $53.1 \mathrm{mg} / 100 \mathrm{~g}$ dry weight & \\
\hline & & Kaempferol-(HMG)-rhamnoside & $4 \mathrm{mg} / 100 \mathrm{~g}$ dry weight & \\
\hline \multirow[t]{2}{*}{ Celery (leaves) } & Flavones & Apigenin & $152.4 \mathrm{mg} / \mathrm{kg}$ fresh weight & [90] \\
\hline & & Luteolin & $228.9 \mathrm{mg} / \mathrm{kg}$ fresh weight & \\
\hline \multirow[t]{2}{*}{ Shiso } & Flavones & Apigenin- $O$-glycosides & $280-920 \mathrm{mg} / 100 \mathrm{~g}$ dry weight & [91] \\
\hline & & Luteolin-O-glycosides & 30-790 mg/100 g dry weight & \\
\hline \multirow[t]{4}{*}{ Grape black } & Flavanols & $(+)$-Catechins & $8.94 \mathrm{mg} / 100 \mathrm{~g}$ & [92] \\
\hline & & (-)-Epicatechins & $8.64 \mathrm{mg} / 100 \mathrm{~g}$ & \\
\hline & & (-)-Epicatechins-3-O-gallate & $2.81 \mathrm{mg} / 100 \mathrm{~g}$ & \\
\hline & & (-)-Epigallocatechin & $0.08 \mathrm{mg} / 100 \mathrm{~g}$ & \\
\hline \multirow[t]{4}{*}{ Apple } & Flavanols & Catechins & $1.66 \mathrm{mg} / 100 \mathrm{~g}$ & [93] \\
\hline & & Epicatechins & $7.72 \mathrm{mg} / 100 \mathrm{~g}$ & \\
\hline & & Procyanidin B1 & $2.71 \mathrm{mg} / 100 \mathrm{~g}$ & \\
\hline & & Procyanidin B2 & $8.58 \mathrm{mg} / 100 \mathrm{~g}$ & \\
\hline \multirow[t]{6}{*}{ Blueberry } & Anthocyanins & Malvidin-3-galactoside & $39.1 \mathrm{mg} / 100 \mathrm{~g}$ & [94] \\
\hline & & Delpinidin-3-galactoside & $25.6 \mathrm{mg} / 100 \mathrm{~g}$ & \\
\hline & & Malvinidin-3-arabinoside & $19.8 \mathrm{mg} / 100 \mathrm{~g}$ & \\
\hline & & Delphinidin-3-arabinoside & $15.8 \mathrm{mg} / 100 \mathrm{~g}$ & \\
\hline & & Petunidin-3-glucoside & $16.6 \mathrm{mg} / 100 \mathrm{~g}$ & \\
\hline & & Petunidin-3-arabinoside & $14.8 \mathrm{mg} / 100 \mathrm{~g}$ & \\
\hline \multirow{3}{*}{$\begin{array}{l}\text { Purple wheat } \\
\text { skin }\end{array}$} & Anthocyanins & Cyanidin malonyl glucoside & $9141.97 \mathrm{mg} / 100 \mathrm{~g}$ & [95] \\
\hline & & Cyanidin-3-galactoside & $2393 \mathrm{mg} / 100 \mathrm{~g}$ & \\
\hline & & Cyanidin acetyl galactoside & $330.49 \mathrm{mg} / 100 \mathrm{~g}$ & \\
\hline
\end{tabular}


Table 1. Food Sources of flavonoids (Continued)

\begin{tabular}{|c|c|c|c|c|}
\hline Source & Flavonoid type & Compound & Mean content & Ref \\
\hline Purple wheat & Anthocyanins & Cyanidin di-glucoside & $267.60 \mathrm{mg} / 100 \mathrm{~g}$ & \\
\hline \multirow[t]{2}{*}{ skin } & & Pelargonidin-3-glucoside & $113.06 \mathrm{mg} / 100 \mathrm{~g}$ & \\
\hline & & Peonidin glucoside & $191.09 \mathrm{mg} / 100 \mathrm{~g}$ & \\
\hline White & Flavanones & Isonaringin & $13.42 \mathrm{mg} / \mathrm{g}$ dry weight & [96] \\
\hline \multirow[t]{9}{*}{ Grapefruit } & & Naringin & $160.25 \mathrm{mg} / \mathrm{g}$ dry weight & \\
\hline & & Hesperidin & $3.23 \mathrm{mg} / \mathrm{g}$ dry weight & \\
\hline & & Neohesperidin & $3.30 \mathrm{mg} / \mathrm{g}$ dry weight & \\
\hline & & Naringenin & $8.49 \mathrm{mg} / \mathrm{g}$ dry weight & \\
\hline & & Hesperetin & $2.93 \mathrm{mg} / \mathrm{g}$ dry weight & \\
\hline & & Isosinensetin & $3.02 \mathrm{mg} / \mathrm{g}$ dry weight & \\
\hline & & Sinensetin & $2.10 \mathrm{mg} / \mathrm{g}$ dry weight & \\
\hline & & Nobiletin & $2.36 \mathrm{mg} / \mathrm{g}$ dry weight & \\
\hline & & Tangeretin & $2.45 \mathrm{mg} / \mathrm{g}$ dry weight & \\
\hline Orange & Flavanones & Naringenin-7-O-glucoside & $0.6 \mathrm{mg} / \mathrm{L}$ & [97] \\
\hline \multirow[t]{6}{*}{ (Juice) } & & Naringenin-7-O-rutinoside & $363.7 \mathrm{mg} / \mathrm{L}$ & \\
\hline & & Hesperetin-7-O-rutinoside & $274.9 \mathrm{mg} / \mathrm{L}$ & \\
\hline & & Hesperetin-7-O-glucoside & $11.5 \mathrm{mg} / \mathrm{L}$ & \\
\hline & & Isosakuranetin-7-O-rutinoside & $47.9 \mathrm{mg} / \mathrm{L}$ & \\
\hline & & Naringenin & $0.1 \mathrm{mg} / \mathrm{L}$ & \\
\hline & & Hesperetin & $0.2 \mathrm{mg} / \mathrm{L}$ & \\
\hline \multirow[t]{6}{*}{ Soybeans } & Isoflavones & Malonilgenistin & $1.879 \mu \mathrm{mole} / \mathrm{g}$ & [43] \\
\hline & & Malonildaidzin & $1.336 \mu \mathrm{mole} / \mathrm{g}$ & \\
\hline & & Malonilglisitin & $0.576 \mu \mathrm{mole} / \mathrm{g}$ & \\
\hline & & Daidzin & $0.030 \mu \mathrm{mole} / \mathrm{g}$ & \\
\hline & & Genistin & $0.057 \mu \mathrm{mole} / \mathrm{g}$ & \\
\hline & & Glycitin & $0.018 \mu \mathrm{mole} / \mathrm{g}$ & \\
\hline \multirow[t]{8}{*}{ Chickpeas } & Isoflavones & Ononin (daidzein derivative) & $0.06 \mathrm{mg} / \mathrm{g}$ & [98] \\
\hline & & Daidzein & $0.12 \mathrm{mg} / \mathrm{g}$ & \\
\hline & & Sissotrin & $0.075 \mathrm{mg} / \mathrm{g}$ & \\
\hline & & Formononetin & $0.10 \mathrm{mg} / \mathrm{g}$ & \\
\hline & & Biochanin A & $0.18 \mathrm{mg} / \mathrm{g}$ & \\
\hline & & Biochanin glucoside & $0.08 \mathrm{mg} / \mathrm{g}$ & \\
\hline & & Biochanin A glucoside Malonylated & $0.06 \mathrm{mg} / \mathrm{g}$ & \\
\hline & & Genistein & $0.06 \mathrm{mg} / \mathrm{g}$ & \\
\hline
\end{tabular}

\section{- CONCLUSION}

Diabetes is a disease caused by several factors, one of which is due to an unhealthy lifestyle pattern. Diabetes can be triggered due to high glucose absorption into the blood. This disease can be overcome by insulin injections, but the provision of insulin, in the long run, has side effects on the body. Flavonoid compounds are known to be an alternative for the treatment of diabetes because these compounds can inhibit the activity of the $\alpha$-amylase and $\alpha$-glucosidase enzymes. In addition, flavonoids can interact with starch to form covalent bonds resulting in starch resistance to digestion. Flavonoids can also inhibit glucose absorption by modulating the function or the expression of glucose transporters. Therefore, flavonoid compounds are a potential alternative treatment for diabetics. In the future, to expand our knowledge on the effect of flavonoids on diabetes disease, studies on the interaction of flavonoids with 
other compounds in the food matrix are suggested, given that such interaction may affect flavonoid bioavailability, which is another important parameter determining the effect of flavonoids in a cellular level. Intervention study using human volunteers to reveal the role of flavonoids in real applications is important to further investigate.

\section{- AUTHOR CONTRIBUTIONS}

Tsani Adiyanti co-wrote the manuscript. Yana Cahyana co-wrote and revised the manuscript. All authors agreed to the final version of this manuscript.

\section{- REFERENCES}

[1] Fitrullah, and Rousdy, A., 2017, Effectiveness of Acupressure at the Zusanli (ST-36) Acupoint as a Comfortable Treatment for Diabetes Mellitus: A Pilot Study in Indonesia, JAMS J. Acupunct. Meridian Stud., 10 (2), 96-103.

[2] Nair, A.S., Bagchi, D., Lehmann, T.E., and Nair, S., 2018, "Renal Sodium-Glucose Transporter-2 Inhibitors as Antidiabetic Agents" in Nutritional and Therapeutic Interventions for Diabetes and Metabolic Syndrome, $2^{\text {nd }}$ Ed., Academic Press, Cambridge, MA, United States, 207-2014.

[3] Tariq, A., Sadia, S., Fan, Y., Ali, S., Amber, R., Mussarat, S., Ahmad, M., Murad, W., Zafar, M., and Adnan, M., 2020, Herbal medicines used to treat diabetes in Southern regions of Pakistan and their pharmacological evidence, J. Herb. Med., 21, 100323.

[4] Whiting, D.R., Guariguata, L., Weil, C., and Shaw, J., 2011, IDF Diabetes Atlas: Global estimates of the prevalence of diabetes for 2011 and 2030, Diabetes Res. Clin. Pract., 94 (3), 311-321.

[5] Aleali, A.M., Payami, S.P., Latifi, S.M., Yazdanpanah, L., Hesam, S., and Khajeddin, N., 2018, Evaluation of psychological resistance to insulin treatment in type II diabetic patients, Diabetes Metab. Syndr., 12 (6), 929-932.

[6] Castagneto-Gissey, L., Angelini, G., Casella-Mariolo, J.R., Marini, P., Mingrone, G., and Casella, G., 2020, The jejunum is the key factor in insulin resistance, Surg. Obes. Relat. Dis., 16 (4), 509-519.

[7] Xu, P., Marsafari, M., Zha, J., and Koffas, M., 2020,
Microbial coculture for flavonoid synthesis, Trends Biotechnol., 38 (7), 686-688.

[8] Farombi, E.O., Akinmoladun, A.C., and Owumi, S.E., 2019, "Anti-cancer foods: Flavonoids" in Encyclopedia of Food Chem., Volume 3, Eds. Melton, L., Shahidi, F., and Varelis, P., Academic Press, Cambridge, MA, United States, 224-236.

[9] Ademiluyi, A.O., and Oboh, G., 2013, Soybean phenolic-rich extracts inhibit key-enzymes linked to type 2 diabetes ( $\alpha$-amylase and $\alpha$-glucosidase) and hypertension (angiotensin I converting enzyme) in vitro, Exp. Toxicol. Pathol., 65 (3), 305309.

[10] Proença, C., Freitas, M., Ribeiro, D., Tomé, S.M., Oliveira, E.F.T., Viegas, M.F., Araújo, A.N., Ramos, M.J., Silva, A.M.S., Fernandes, P.A., and Fernandes, E., 2019, Evaluation of a flavonoids library for inhibition of pancreatic a-amylase towards a structure-activity relationship, J. Enzyme Inhib. Med. Chem., 34 (1), 577-588.

[11] Costa, T.M., Mayer, D.A., Siebert, D.A., Micke, G.A., Alberton, M.D., Tavares, L.B.B., and de Oliveira, D., 2020, Kinetics analysis of the inhibitory effects of alpha-glucosidase and identification of compounds from Ganoderma lipsiense mycelium, Appl. Biochem. Biotechnol., 191 (3), 996-1009.

[12] Goto, T., Horita, M., Nagai, H., Nagatomo, A., Nishida, N., Matsuura, Y., and Nagaoka, S., 2012, Tiliroside, a glycosidic flavonoid, inhibits carbohydrate digestion and glucose absorption in the gastrointestinal tract, Mol. Nutr. Food Res., 56 (3), 435-445.

[13] Takahama, U., and Hirota, S., 2018, Interactions of flavonoids with $\alpha$-amylase and starch slowing down its digestion, Food Funct., 9 (2), 677-687.

[14] Hussain, T., Tan, B., Murtaza, G., Liu, G., Rahu, N., Saleem Kalhoro, M., Hussain Kalhoro, D., Adebowale, T.O., Usman Mazhar, M., Rehman, Z., Martínez, Y., Akber Khan, S., and Yin, Y., 2020, Flavonoids and type 2 diabetes: Evidence of efficacy in clinical and animal studies and delivery strategies to enhance their therapeutic efficacy, Pharmacol. 
Res., 152, 104629.

[15] Chiang, Y.C., Chen, C.L., Jeng, T.L., Lin, T.C., and Sung, J.M., 2014, Bioavailability of cranberry bean hydroalcoholic extract and its inhibitory effect against starch hydrolysis following in vitro gastrointestinal digestion, Food Res. Int., 64, 939945.

[16] Ballard, C.R., and Maróstica, M.R., 2019, "Health benefits of flavonoids" in Bioactive Compounds, Woodhead Publishing Cambridge, MA, United States, 185-201.

[17] Tan, H., Man, C., Xie, Y., Yan, J., Chu, J., and Huang, J., 2019, A crucial role of GA-regulated flavonol biosynthesis in root growth of Arabidopsis, Mol. Plant, 12 (4), 521-537.

[18] Campone, L., Celano, R., Piccinelli, A.L., Pagano, I., Carabetta, S., Di Sanzo, R., Russo, M., Ibañez, E., Cifuentes, A., and Rastrelli, L., 2018, Response surface methodology to optimize supercritical carbon dioxide/co-solvent extraction of brown onion skin by-product as source of nutraceutical compounds, Food Chem., 269, 495-502.

[19] Endo, S., Matsuoka, T., Nishiyama, T., Arai, Y., Kashiwagi, H., Abe, N., Oyama, M., Matsunaga, T., and Ikari, A., 2019, Flavonol glycosides of Rosa multiflora regulates intestinal barrier function through inhibiting claudin expression in differentiated Caco-2 cells, Nutr. Res., 72, 92-104.

[20] Kimura, H., Ogawa, S., Ishihara, T., Maruoka, M., Tokuyama-Nakai, S., Jisaka, M., and Yokota, K., 2017, Antioxidant activities and structural characterization of flavonol $\mathrm{O}$-glycosides from seeds of Japanese horse chestnut (Aesculus turbinata BLUME), Food Chem., 228, 348-355.

[21] Chen, Y., Chen, Q., Wang, X., Sun, F., Fan, Y., Liu, X., Li, H., and Deng, Z., 2020, Hemostatic action of lotus leaf charcoal is probably due to transformation of flavonol aglycons from flavonol glycosides in traditional Chinses medicine, J. Ethnopharmacol., $249,112364$.

[22] Xie, L., Cao, Y., Zhao, Z., Ren, C., Xing, M., Wu, B., Zhang, B., Xu, C., Chen, K., and Li, X., 2020, Involvement of MdUGT75B1 and MdUGT71B1 in flavonol galactoside/glucoside biosynthesis in apple fruit, Food Chem., 312, 126124.

[23] Cassidy, A., and Kay, C., 2013, "Phytochemicals: Classification and occurrence" in Encyclopedia of Human Nutrition, $3^{\text {rd }}$ Ed., Eds. Caballero, B., Academia Press, Cambridge, MA, United States, 39-46.

[24] Sharma, A., Tuli, H.S., Kashyap, D., and Sharma, A.K., 2019, "Flavones: Flavonoids having chemicobiological properties with a preview into anticancer action mechanism" in Bioactive Natural Products for the Management of Cancer from Bench to Bedside, Eds. Sharma, A., Springer, Singapore, 7189.

[25] Chua, L.S., Abdullah, F.I., and Awang, M.A., 2020, Potential of natural bioactive C-glycosyl flavones for antidiabetic properties, Stud. Nat. Prod. Chem., 64, 241-261.

[26] Jiang, N., Doseff, A.I., and Grotewold, E., 2016, Flavones: From biosynthesis to health benefits, Plants, 5 (2), 27.

[27] Arroo, R.R.J., Şöhretoğlu, D., Spandidos, D.A., and Androutsopoulos, V.P., 2017, Anticancer potential of flavones, Proceedings, 1 (10), 975.

[28] Li, X., Wang, X., Li, C., Khutsishvili, M., Fayvush, G., Atha, D., Zhang, Y., and Borris, R.P., 2019, Unusual flavones from Primula macrocalyx as inhibitors of OAT1 and OAT3 and as antifungal agents against Candida rugosa, Sci. Rep., 9 (1), 9230.

[29] Duarte, S., Arango, D., Parihar, A., Hamel, P., Yasmeen, R., and Doseff, A.I., 2013, Apigenin protects endothelial cells from lipopolysaccharide (LPS)-induced inflammation by decreasing caspase- 3 activation and modulating mitochondrial function, Int. J. Mol. Sci., 14 (9), 17664-17679.

[30] Mena, P., Domínguez-Perles, R., GironésVilaplana, A., Baenas, N., García-Viguera, C., and Villaño, D., 2014, Flavan-3-ols, anthocyanins, and inflammation, IUBMB Life, 66 (11), 745-758.

[31] Wang, H., Provan, G.J., and Helliwell, K., 2000, Tea flavonoids: Their functions, utilisation and analysis, Trends Food Sci. Technol., 11 (4-5), 152-160.

[32] Barrett, A.H., Farhadi, N.F., and Smith, T.J., 2018, 
Slowing starch digestion and inhibiting digestive enzyme activity using plant flavanols/tannins- A review of efficacy and mechanisms, LWT Food Sci. Technol., 87, 394-399.

[33] Pons, Z., Margalef, M., Bravo, F.I., Arola-Arnal, A., and Muguerza, B., 2016, Grape seed flavanols decrease blood pressure via Sirt-1 and confer a vasoprotective pattern in rats, J. Funct. Foods, 24, 164-172.

[34] Rull, G., Mohd-Zain, Z.N., Shiel, J., Lundberg, M.H., Collier, D.J., Johnston, A., Warner, T.D., and Corder, R., 2015, Effects of high flavanol dark chocolate on cardiovascular function and platelet aggregation, Vascul. Pharmacol., 71, 70-78.

[35] Grzesik, M., Bartosz, G., Dziedzic, A., Narog, D., Namiesnik, J., and Sadowska-Bartosz, I., 2018, Antioxidant properties of ferrous flavanol mixtures, Food Chem., 268, 567-576.

[36] Griffin, L.E., Fausnacht, D.W., Tuzo, J.L., Addington, A.K., Racine, K.C., Zhang, H., Hughes, M.D., England, K.M., Bruno, R.S., O’Keefe, S.F., Neilson, A.P., and Stewart, A.C., 2019, Flavanol supplementation protects against obesity-associated increases in systemic interleukin-6 levels without inhibiting body mass gain in mice fed a high-fat diet, Nutr. Res., 66, 32-47.

[37] Meng, H.C., Gao, J., Zheng, H.C., Damirin, A., and Ma, C.M., 2015, Diacetylated and acetoneconjugated flavan-3-ols as potent antioxidants with cell penetration ability, J. Funct. Foods, 12, 256-261.

[38] Balzer, J., Rassaf, T., Heiss, C., Kleinbongard, P., Lauer, T., Merx, M., Heussen, N., Gross, H.B., Keen, C.L., Schroeter, H., and Kelm, M., 2008, Sustained benefits in vascular function through flavanolcontaining cocoa in medicated diabetic patients: A double-masked, randomized, controlled trial, J. Am. Coll. Cardiol., 51 (22), 2141-2149.

[39] Ajmala Shireen, P., Abdul Mujeeb, V.M., and Muraleedharan, K., 2017, Theoretical insights on flavanones as antioxidants and UV filters: A TDDFT and NLMO study, J. Photochem. Photobiol., B, 170, 286-294.

[40] Escudero-López, B., Cerrillo, I., Herrero-Martín, G.,
Hornero-Méndez, D., Gil-Izquierdo, A., Medina, S., Ferreres, F., Berná, G., Martín, F., and FernándezPachón, M.S., 2013, Fermented orange juice: Source of higher carotenoid and flavanone contents, $J$. Agric. Food Chem., 61 (37), 8773-8782.

[41] Lee, J.H., 2015, In-vitro evaluation for antioxidant and anti-inflammatory property of flavanone derivatives, Food Biosci., 11, 1-7.

[42] Hsiao, Y.C., Kuo, W.H., Chen, P.N., Chang, H.R., Lin, T.H., Yang, W.E., Hsieh, Y.S., and Chu, S.C., 2007, Flavanone and 2'-OH flavanone inhibit metastasis of lung cancer cells via down-regulation of proteinases activities and MAPK pathway, Chem. Biol. Interact., 167 (3), 193-206.

[43] Kim, E.H., Lee, O.K., Kim, J.K., Kim, S.L., Lee, J., Kim, S.H., and Chung, I.M., 2014, Isoflavones and anthocyanins analysis in soybean (Glycine max (L.) Merill) from three different planting locations in Korea, F. Crop. Res., 156, 76-83.

[44] Teekachunhatean, S., Hanprasertpong, N., and Teekachunhatean, T., 2013, Factors affecting isoflavone content in soybean seeds grown in Thailand, Int. J. Agron., 2013, 1-11.

[45] Watanabe, S., Yamada, R., Kanetake, H., Kaga, A., and Anai, T., 2019, Identification and characterization of a major QTL underlying soybean isoflavone malonylglycitin content, Breed. Sci., 69 (4), 564-572.

[46] Wei, P., Liu, M., Chen, Y., and Chen, D.C., 2012, Systematic review of soy isoflavone supplements on osteoporosis in women, Asian Pac. J. Trop. Med., 5 (3), 243-248.

[47] Wang, Q., Ge, X., Tian, X., Zhang, Y., Zhang, J., and Zhang, P., 2013, Soy isoflavone: The multipurpose phytochemical (Review), Biomed. Rep., 1 (5), 697701.

[48] Lu, Y., An, Y., Lv, C., Ma, W., Xi, Y., and Xiao, R., 2018, Dietary soybean isoflavones in Alzheimer's disease prevention, Asia Pac. J. Clin. Nutr., 27 (5), 946-954.

[49] Wada, K., Nakamura, K., Tamai, Y., Tsuji, M., Kawachi, T., Hori, A., Takeyama, N., Tanabashi, S., Matsushita, S., Tokimitsu, N., and Nagata, C., 2013, 
Soy isoflavone intake and breast cancer risk in Japan: From the Takayama study, Int. J. Cancer, 133 (4), 952-960.

[50] Santos-Buelga, C., and Gonzáles-Paramás, A.M., 2019, “Anthocyanins" in Encyclopedia of Food Chemistry, Volume 1, Eds. Melton, L., Shahidi, F., and Varelis, P., Academic Press, Oxford, United Kingdom, 10-21.

[51] Guo, H., and Xia, M., 2018, "Anthocyanins and diabetes regulation" in Polyphenols: Mechanisms of Action in Human Health and Disease, $2^{\text {nd }}$ Ed., Eds. Watson, R.R., Preedy, V.R., and Zibadi, S., Academic Press, Cambridge, MA, United States, 135-145.

[52] Cahyana, Y., and Gordon, M.H., 2013, Interaction of anthocyanins with human serum albumin: Influence of $\mathrm{pH}$ and chemical structure on binding, Food Chem., 141 (3), 2278-2285.

[53] Castro-Acosta, M.L., Stone, S.G., Mok, J.E., Mhajan, R.K., Fu, C.I., Lenihan-Geels, G.N., Corpe, C.P., and Hall, W.L., 2017, Apple and blackcurrant polyphenol-rich drinks decrease postprandial glucose, insulin and incretin response to a highcarbohydrate meal in healthy men and women, $J$. Nutr. Biochem., 49, 53-62.

[54] Castro-Acosta, M.L., Smith, L., Miller, R.J., McCarthy, D.I., Farrimond, J.A., and Hall, W.L., 2016, Drinks containing anthocyanin-rich blackcurrant extract decrease postprandial blood glucose, insulin and incretin concentrations, J. Nutr. Biochem., 38, 154-161.

[55] Barik, S.K., Russell, W.R., Moar, K.M., Cruickshank, M., Scobbie, L., Duncan, G., and Hoggard, N., 2020, The anthocyanins in black currants regulate postprandial hyperglycaemia primarily by inhibiting a-glucosidase while other phenolics modulate salivary a-amylase, glucose uptake and sugar transporters, J. Nutr. Biochem., 78, 108325.

[56] Gomes, J.V.P., Rigolon, T.C.B., Souza, M.S.S., Alvarez-Leite, J.I., Lucia, C.M.D., Martino, H.S.D., and Rosa, C.O.B., 2019, Antiobesity effects of anthocyanins on mitochondrial biogenesis, inflammation, and oxidative stress: A systematic review, Nutrition, 66, 192-202.
[57] Lin, B.W., Gong, C.C., Song, H.F., and Cui, Y.Y., 2017, Effects of anthocyanins on the prevention and treatment of cancer, Br. J. Pharmacol., 174 (11), 1226-1243.

[58] Cahyana, Y., Gordon, M.H., and Gibson, T.M., 2019, Urinary excretion of anthocyanins following consumption of strawberry and red grape juice, Int. J. Vitam. Nutr. Res., 89 (1-2), 29-36.

[59] Fernández-Acosta, K., Salmeron, I., Chavez-Flores, D., Perez-Reyes, I., Ramos, V., Ngadi, M., Kwofie, E.M., and Perez-Vega, S., 2019, Evaluation of different variables on the supercritical $\mathrm{CO}_{2}$ extraction of oat (Avena sativa L.) oil; Main fatty acids, polyphenols, and antioxidant content, $J$. Cereal Sci., 88, 118-124.

[60] Mayer, J., and Donnely, T.M., 2013, “Amylase" in Clinical Veterinary Advisor: Birds Exotic Pets, W.B. Saunders, Saint Louis, USA, 602-603.

[61] Abd-Elaziz, A.M., Karam, E.A., Ghanem, M.M., Moharam, M.E., and Kansoh, A.L., 2020, Production of a novel $\alpha$-amylase by Bacillus atrophaeus $\mathrm{NRC1}$ isolated from honey: Purification and characterization, Int. J. Biol. Macromol., 148, 292-301.

[62] Krishnan, M., Nagendran, N.A., Pandiaraja, D., and Moorthi, P.V., 2017, Isolation and characterization of amylase producers and optimization of enzyme production, Int. J. Dev. Res., 7 (12), 18128-18134.

[63] Tiwari, S., Srivastava, R., Singh, C.S., Shukla, K., Singh, R.K., Singh, P., Singh, R., Singh, N.L., and Sharma, R., 2015, Amylases: An overview with special reference to alpha amylase, J. Global Biosci., 4 (SI 1), 1886-1901.

[64] Sun, L., Warren, F.J., and Gidley, M.J., 2019, Natural products for glycaemic control: Polyphenols as inhibitors of alpha-amylase, Trends Food Sci. Technol., 91, 262-273.

[65] Hasimun, P., and Adnyana, I.K., 2019, "Zingiberaceae family effects on alpha-glucosidase activity: Implication for diabetes" in Bioactive Food as Dietary Interventions for Diabetes, $2^{\text {nd }}$ Ed., Eds. Watson, R.R., and Preedy, V.R., Academic Press, Cambridge, MA, United States, 387-393. 
[66] Lo Piparo, E., Scheib, H., Frei, N., Williamson, G., Grigorov, M., and Chou, C.J., 2008, Flavonoids for controlling starch digestion: Structural requirements for inhibiting human a-amylase, J. Med. Chem., 51 (12), 3555-3561.

[67] Pascual, J.M., Wang, D., and De Vivo, D.C., 2015, Glucose transporter type I deficiency and other glucose flux disorders, in Rosenberg's Molecular and Genetic Basis of Neurological and Psychiatric Disease, $5^{\text {th }}$ Ed., Eds. Rosenberg, R.N., and Pascual, J.M., Academic Press, Boston, MA, United States, 649662.

[68] Chiang, Y.C., Chen, C.L., Jeng, T.L., and Sung, J.M., 2014, In vitro inhibitory effects of cranberry bean (Phaseolus vulgaris L.) extracts on aldose reductase, a-glucosidase and a-amylase, Int. J. Food Sci. Technol., 49 (6), 1470-1479.

[69] Yuan, E., Liu, B., Wei, Q., Yang, J., Chen, L., and Li, Q., 2014, Structure activity relationships of flavonoids as potent $\alpha$-amylase inhibitors, NPC Nat. Prod. Commun., 9 (8), 1-4.

[70] Gopinath, S.C.B., Anbu, P., Arshad, M.K., Lakshmipriya, T., Voon, C.H., Hashim, U., and Chinni, S.V, 2017, Biotechnological processes in microbial amylase production, Biomed Res. Int., 2017, 1272193.

[71] Lotulung, P.D.N., Mozef, T., Risdian, C., and Darmawan, A., 2014, In vitro antidiabetic activities of extract and isolated flavonoid compounds from Artocarpus altilis (Parkinson) Fosberg, Indones. J. Chem., 14 (1), 7-11.

[72] Anisah, L.N., Syafii, W., Pari, G., and Sari, R.K., 2018, Antidiabetic activities and identification of chemical compound from samama (Anthocephalus macrophyllus (Roxb) Havil), Indones. J. Chem., 18 (1), 66-74.

[73] Wu, X., Hu, M., Hu, X., Ding, H., Gong, D., and Zhang, G., 2019, Inhibitory mechanism of epicatechin gallate on $\alpha$-amylase and $\alpha$-glucosidase and its combinational effect with acarbose or epigallocatechin gallate, J. Mol. Liq., 290, 111202.

[74] Luo, F., Liu, X., She, Y., and Gao, W., 2018, Three Citrus flavonoids retard the digestion of starch and its working mechanisms, Int. J. Food Sci. Technol., 53 (2), 365-371.

[75] Navale, A., 2019, "Glucose transporters and their cellular form, role and function" in Molecular Nutrition: Carbohydrates, Eds. Patel, V.B., Academic Press, Cambridge, MA, United States, 21-34.

[76] Bryant, N.J., Govers, R., and James, D.E., 2002, Regulated transport of the glucose transporter GLUT4, Nat. Rev. Mol. Cell Biol., 3 (4), 267-277.

[77] Govers, R., 2014, Cellular regulation of glucose uptake by glucose transporter GLUT4, Adv. Clin. Chem., 66, 173-240.

[78] Al-Ishaq, R.K., Abotaleb, M., Kubatka, P., Kajo, K., and Büsselberg, D., 2019, Flavonoids and their antidiabetic effects: Cellular mechanisms and effects to improve blood sugar levels, Biomolecules, 9 (9), 430.

[79] Manzano, S., and Williamson, G., 2010, Polyphenols and phenolic acids from strawberry and apple decrease glucose uptake and transport by human intestinal Caco-2 cells, Mol. Nutr. Food Res., 54 (12), 1773-1780.

[80] Kwon, O., Eck, P., Chen, S., Corpe, C.P., Lee, J., Kruhlak, M., and Levine, M., 2007, Inhibition of the intestinal glucose transporter GLUT2 by flavonoids, FASEB J., 21 (2), 366-377.

[81] Goodrich, J.A., and Kugel, J.F., 2007, Binding and kinetics for molecular biologists, Q. Rev. Biol., 82 (3), 268-269.

[82] Mi, Y., Qi, G., Gao, Y., Li, R., Wang, Y., Li, X., Huang, S., and Liu, X., 2017, (-)-Epigallocatechin3-gallate ameliorates insulin resistance and mitochondrial dysfunction in HepG2 cells: Involvement of Bmal1, Mol. Nutr. Food Res., 61 (12), 1700440.

[83] Pitura, K., and Arntfield, S.D., 2019, Characteristics of flavonol glycosides in bean (Phaseolus vulgaris L.) seed coats, Food Chem., 272, 26-32.

[84] Bittner, K., Rzeppa, S., and Humpf, H.U., 2013, Distribution and quantification of flavan-3-ols and procyanidins with low degree of polymerization in nuts, cereals, and legumes, J. Agric. Food Chem., 61 (38), 9148-9154.

[85] Hu, B., Liu, X., Zhang, C., and Zeng, X., 2017, Food 
macromolecule based nanodelivery systems for enhancing the bioavailability of polyphenols, J. Food Drug Anal., 25 (1), 3-15.

[86] Lachos-Perez, D., Baseggio, A.M., Mayanga-Torres, P.C., Maróstica, M.R., Rostagno, M.A., Martínez, J., and Forster-Carneiro, T., 2018, Subcritical water extraction of flavanones from defatted orange peel, $J$. Supercrit. Fluids, 138, 7-16.

[87] Lee, M.J., Chung, I.M., Kim, H., and Jung, M.Y., 2015, High resolution LC-ESI-TOF-mass spectrometry method for fast separation, identification, and quantification of 12 isoflavones in soybeans and soybean products, Food Chem., 176, 254-262.

[88] Nugroho, A., Heryani, H., Choi, J.S., and Park, H.J., 2017, Identification and quantification of flavonoids in Carica papaya leaf and peroxynitrite-scavenging activity, Asian Pac. J. Trop. Biomed., 7 (3), 208-213.

[89] Liu, J., Hefni, M.E., and Witthöft, C.M., 2020, Characterization of flavonoid compounds in common Swedish berry species, Foods, 9 (3), 358.

[90] Tsanova-Savova, S., and Ribarova, F., 2013, Flavonols and flavones in some Bulgarian plant foods, Pol. J. Food Nutr. Sci., 63 (3), 173-177.

[91] Hostetler, G.L., Ralston, R.A., and Schwartz, S.J., 2017, Flavones: Food sources, bioavailability, metabolism, and bioactivity, Adv. Nutr., 8 (3), 423-435.

[92] Arts, I.C.W., van de Putte, B., and Hollman, P.C.H., 2000, Catechin contents of foods commonly consumed in The Netherlands. 1. Fruits, vegetables, staple foods, and processed foods, J. Agric. Food Chem., 48 (5), 1746-1751.
[93] Ceymann, M., Arrigoni, E., Schärer, H., Bozzi Nising, A., and Hurrell, R.F., 2012, Identification of apples rich in health-promoting flavan-3-ols and phenolic acids by measuring the polyphenol profile, J. Food Compos. Anal., 26 (1-2), 128-135.

[94] Stevenson, D., and Scalzo, J., 2012, Anthocyanin composition and content of blueberries from around the world, J. Berry Res., 2 (4), 179-189.

[95] Zhang, Y., Lin, Y., Huang, L., Tekliye, M., Rasheed, H.A., and Dong, M., 2020, Composition, antioxidant, and anti-biofilm activity of anthocyanin-rich aqueous extract from purple highland barley bran, LWT Food Sci. Technol., 125, 109181.

[96] Chebrolu, K.K., Jifon, J., and Patil, B.S., 2016, Modulation of flavanone and furocoumarin levels in grapefruits (Citrus paradisi Macfad.) by production and storage conditions, Food Chem., 196, 374-380.

[97] Cao, W., Ye, L.H., Cao, J., Xu, J.J., Peng, L.Q., Zhu, Q.Y., Zhang, Q.Y., and Hu, S.S., 2015, Quantitative analysis of flavanones from citrus fruits by using mesoporous molecular sieve-based miniaturized solid phase extraction coupled to ultrahighperformance liquid chromatography and quadrupole time-of-flight mass spectrometry, $J$. Chromatogr. A, 1406, 68-77.

[98] Gao, Y., Yao, Y., Zhu, Y., and Ren, G., 2015, Isoflavone content and composition in chickpea (Cicer arietinum L.) sprouts germinated under different conditions, J. Agric. Food Chem., 63 (10), 2701-2707. 